\title{
IHTEPB'Ю
}

DOI https://doi.org/10.32848/agrar.innov.2021.5.25

\section{СУЧАСНИЙ СТАН, ПЕРСПЕКТИВИ ТА НАУКОВІ ОСНОВИ СИСТЕМИ НАСІННИЦТВА}

\begin{abstract}
Інформацію про нагальні проблеми в галузі насінництва надає завідувач відділу первинного та елітного насінництва Інституту зрошуваного землеробства Національної академії аграрних наук України, кандидат сільськогосподарських наук, старший науковий співробітник Анатолій Влащук
\end{abstract}

- Який на сьогодні стан та структура насінницької галузі в Херсонській області?

- Виробництвом насіння різних генерацій на Херсонщині займаються три категорії господарств. Перша - це виробники добазового насіння. До них належать наукові установи, дослідні станції та науково-виробнича фрірма «Дріада». Ці суб'єкти насінницької галузі $€$ оригінаторами сортів різних сільськогосподарських культур та виробниками розсадників розмноження. Друга - це виробники базового насіння - супереліти та еліти. До них належать вищеназвані підприємства, дослідні господарства Інституту зрошуваного землеробства НААН та деякі фермерські господарства. Третя ланка галузі - це виробники сертифікованого насіння: в основному ДПДГ та фермерські господарства.

У Херсонській області була розроблена науково-виробнича програма розвитку насінницької галузі «Насінництво Херсонщини» на 2013-2020 роки. Вона була розрахована до 2020 року. Згідно з цієї програмою були заплановані та вироблялися загальні обсяги насіння сільськогосподарських культур різних генерацій для забезпечення потреб аграріїв області та інших споживачів України. Головною установою та виконавцем $€$ Інститут зрошуваного землеробства НААН із системою його дослідних господарств.

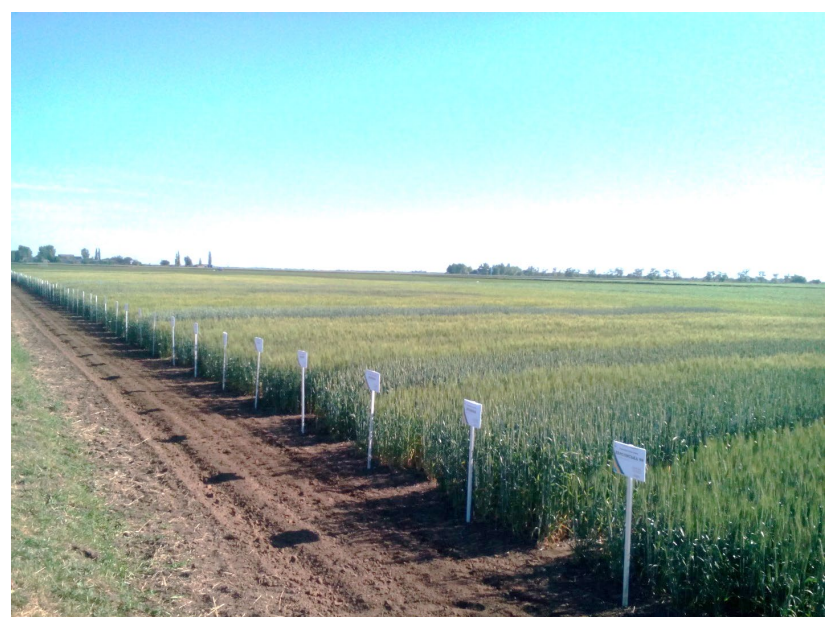

- Які ви можете окреслити наукові основи системи насінництва Півдня України?

- Підвищення ефективності селекції та насінництва має велике значення для стабілізації роботи агропромислового комплексу. Південь України володіє значним сортовим потенціалом різних сільськогосподарських культур. Щорічне виконання плану сортооновлення дозволяє аграріям регіону перейти на сівбу лише сортовим насінням, переважно районованих та перспективних сортів. Натепер у виробництві використовують сорти пшениці озимої та ячменю з потенціалом урожайності 9,0-12,0 т/га, рису - 8,0-10,0 т/га, гібриди кукурудзи - 14,0-15,0 т/га, сорти сої - 4,0-6,5 т/га. У Херсонській області організація насінництва здійснюється згідно із Законом України «Про насіння і садивний матеріал», який набув чинності 20.01.2003 р., який включає основні положення з виробництва, реалізації та використання насіння, правові відношення між виробниками і споживачами насіння. Згідно з цим документом виробництвом і реалізацією сортового насіння мають право займатися фрізичні і юридичні особи, які за своїми виробничими можливостями відповідають вимогам державної атестації та занесені в «Державний реєстр виробників насіннєвого матеріалу» Міністерства аграрної політики та продовольства України.

Система насінництва південного регіону країни побудована на науковій основі, яка забезпечує швидке розмноження та впровадження у виробництво нових сортів сільськогосподарських культур, виробництво сортового насіння в кількості, необхідній для забезпечення сівби та створення страхових фондів. У ринкових умовах сьогодення основою ефективного господарювання $€$ використання інтенсивних технологій вирощування сільськогосподарських культур, які базуються на використанні високопродуктивних сортів та раціональному застосуванні оптимальних елементів технології.

Інститут зрошуваного землеробства НАAН - єдина в Україні наукова установа, де створюють сорти та гібриди для зрошуваного землеробства. В Інституті проводять роботу із селекції пшениці озимої, сої, люцерни, кукурудзи, бавовника, томатів. Відділ насінництва І3З НААН безпосередньо працює над розв'язанням прикладних завдань, розробкою методичних рекомендацій, впровадженням у виробництво науково-технічних програм та науковим забезпеченням агротехніки вирощування високоякісного посівного матеріалу. Основним напрямом наукової діяльності $€$ розробка та удосконалення елементів технологій вирощування насіння сільськогосподарських культур, а саме вивчення процесу фрормування насіннєвої продуктивності зернових, зернобобових, круп'яних, олійних і технічних культур, а також методів їх прискореного розмноження. Співробітниками відділу створено сорт буркуну білого однорічного Південний, який внесено до Державного реєстру сортів рослин. 


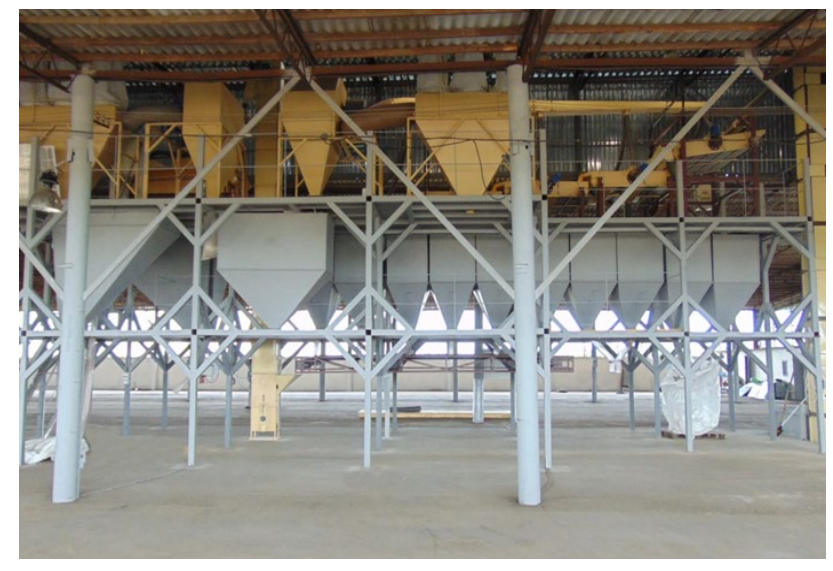

- Виробництвом яких сільськогосподарських культур займається Інститут та його дослідні господарства?

- Виробництво якісного насіннєвого матеріалу - основна мета Інституту зрошуваного землеробства. Натепер I33 НААН володіє значним сортовим потенціалом різних сільськогосподарських культур, які серед товаровиробників користуються великим попитом. Науковцями установи створено та нині внесено до Держреєстру виробників насіннєвого матеріалу 15 сортів пшениці м'якої, які належать до сильних пшениць, характеризуються високими показниками якості зерна, та 3 сорти твердої пшениці озимої, 1 сорт пшениці озимої м'якої перебуває на Держсортовипробуванні; всі сорти культури стійкі до вилягання та осипання; 15 сортів сої від надранніх до пізньостиглих; 10 сортів люцерни, що мають насіннєву продуктивність у межах 4-8 ц/га та відрізняються високою кормовою якістю; 14 гібридів кукурудзи з високим генетичним потенціалом урожайності до 16-18 т/га; 1 сорт буркуну білого однорічного, якому властива висока кормова цінність та рівень збору меду до 600 кг/га; 2 сорти бавовнику, 7 сортів томатів.

Інститут займається науково обґрунтованим веденням первинного та елітного насінництва районованих і перспективних сортів зернових, зернобобових, кормових, технічних культур і багаторічних трав. Високоякісне насіння сприяє максимальній реалізації генетичного потенціалу сортів і гібридів сільськогосподарських культур, а отже, і збільшенню прибутковості насінницьких господарств, зростанню їх конкурентоспроможності.

- Що сприяє отриманню насіння 3 високими посівними якостями?

- Отримати насіння високої якості в процесі післязбиральної доробки можна лише за умови використання сучасного обладнання і оптимальних технологій виробництва. Саме тому в ІЗЗ НААН побудовано універсальний насіннєвий завод вітчизняної розробки. Відкриття насіннєвого заводу інноваційної нетравмуючої пофракційної технології підготовки високорепродуктивного насіння різних сільськогосподарських культур розробки компанії «Завод «Фадєєв Агро» дозволяє отримувати нетравмоване насіння зернових, олійних, технічних культур і багаторічних трав (пшениця, ячмінь, кукурудза, соя, люцерна, буркун, ріпак, льон, соняшник, сорго, просо, гречка та ін.) високих репродукцій. Завод характеризується високою продуктивністю, зокрема зернових культур - 5 т/год, соняшнику - 1,5 т/год. Нетравмуюча пофракційна технологія виробництва дозволяє 3 насіннєвого матеріалу виділити насіння з високими посівними та врожайними якостями, істотно підвищити врожайність у разі збереження родючості ґрунту.

Кожен добрий господар знає, що якісне насіння запорука гарного врожаю, що є джерелом економічного зміцнення і процвітання. Інститут зрошуваного землеробства НААН завжди гарантує високу якість насіння, а використання нового насіннєвого заводу обов'язково підвищить ці гарантії. Таким чином, уже нині українські товаровиробники мають можливість отримати високоякісне насіння еліти, супереліти та інших репродукцій пшениці, ячменя, кукурудзи, сої, соняшника, ріпаку, гороху, люцерни та інших сільськогосподарських культур, вироблене на універсальному насіннєвому заводі розробки компанії «Завод «Фадєєв Агро».

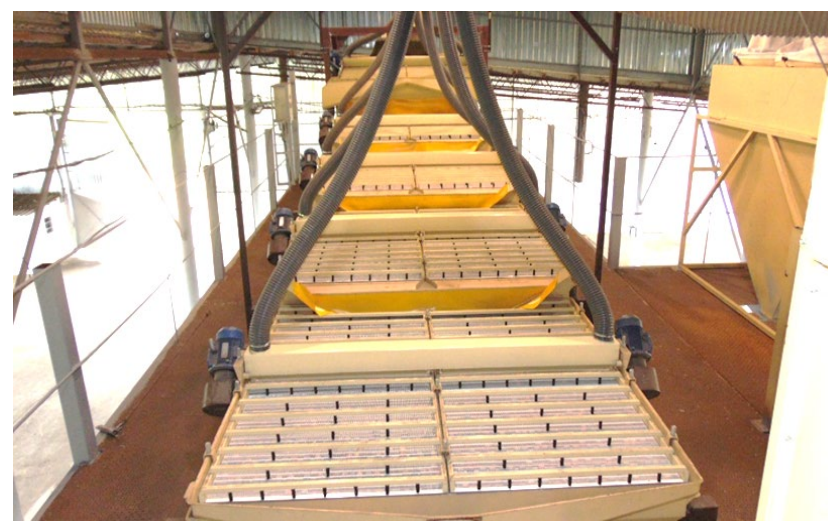

- Які, на ваш погляд, основні проблеми галузі насінництва?

- Це:

а) повільне впровадження у виробництво нових рекомендованих для поширення сортів і гібридів. Це призвело до того, що на полях Херсонщини вирощується понад $50 \%$ сортів зі зниженим рівнем урожайності та адаптивних властивостей, а нові перспективні сорти не використовують. Багато сортів завезено з інших регіонів і країн, вони не пристосовані до умов південного регіону України і не можуть забезпечити необхідний рівень урожайності і валових зборів продукції;

б) недосконала схема виробництва елітного насіння по зернових та інших культурах. За наявної схеми на виробництво еліти втрачається 6 років, це обмежує оперативність у проведенні сортозміни і підвищує собівартість насіннєвої продукції;

в) спостерігається порушення агротехніки на насінницьких посівах, що призводить до біологічного і механічного засмічення сортів, зниження продуктивності рослин, посівних та урожайних властивостей насіння;

г) відсутній завод з переробки насіння кукурудзи;

ґ) втрачено значну частину ринків збуту у секторі овоче-баштанних культур. Порушені взаємодії між 
сфрерами виробництва, збуту, переробки і зберігання. Значна частина валового виробництва овоче-баштанних культур зосереджена у приватному секторі, де використовується насіння низьких, часто невідомих репродукцій, а сортозаміна і сортооновлення практично не проводиться або проводиться стихійно.

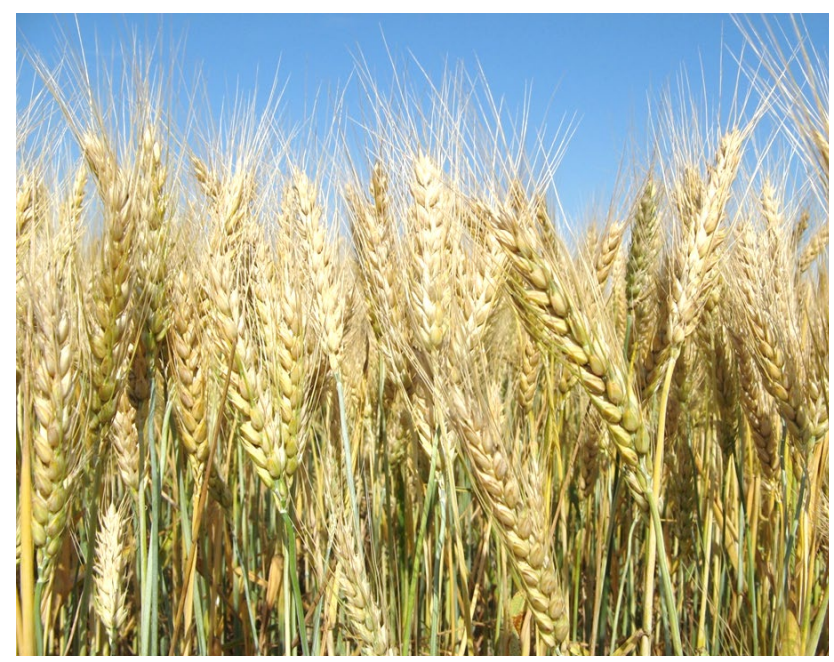

- Що ви пропонуєте для прискореного впровадження у виробництво нових сортів сільськогосподарських культур?

- 3 метою прискореного розмноження нових (у тому числі перспективних) сортів якомога інтенсивніше використовувати:

а) способи вирощування сортових посівів, які сприяють підвищенню коефіцієнта розмноження насіння - застосування зрошення, оптимальних норми висіву та строків сівби, кращих попередників (пар, зернобобові), способів сівби тощо;

б) у первинному (добазовому) насінництві паралельно з використанням індивідуального добору використовувати масовий, який дозволяє скорочувати термін виробництва елітного (базового) насіння на 2-3 роки, збільшувати валові збори насіння у розсадниках розмноження, підтримувати високі сортоспецифічні, посівні та урожайні властивості насіння;

в) у первинному, елітному, репродукційному, а також у внутрігосподарському насінництві не допускати порушень сортової технології вирощування озимої пшениці; у цій справі наявна єдина принципова заповідь: не нашкодь! Слід дотримуватись Закону України «Про насіння та посадковий матеріал», інших законодавчих актів. 